\title{
The Thaayorre 'true man': Lexicon of the human body in an Australian language
}

\author{
Alice R. Gaby \\ Max Planck Institute for Psycholinguistics, Postbus 310, 6500 AH Nijmegen, The Netherlands
}

\begin{abstract}
Segmentation (and, indeed, definition) of the human body in Kuuk Thaayorre (a Paman language of Cape York Peninsula, Australia) is in some respects typologically unusual, while at other times it conforms to cross-linguistic patterns. The process of deriving complex body part terms from monolexemic items is revealing of metaphorical associations between parts of the body. Associations between parts of the body and entities and phenomena in the broader environment are evidenced by the ubiquity of body part terms (in their extended uses) throughout Thaayorre speech. Understanding the categorisation of the body is therefore prerequisite to understanding the Thaayorre language and worldview.

(c) 2005 Elsevier Ltd. All rights reserved.
\end{abstract}

Keywords: Kuuk Thaayorre; Australian languages; Body part terms; Partonomy; Meronymy; Semantic fields; Polysemy

\section{Introduction}

This paper presents the first detailed analysis of how the body and its parts are lexicalised in Kuuk Thaayorre, ${ }^{1}$ a Paman language spoken on the west coast of Cape York

\footnotetext{
E-mail address: alice.gaby@mpi.nl

1 Note that the Thaayorre generic noun kuuk (meaning 'language') is included in the language name Kuuk Thaayorre. This bipartite term is borrowed into English as a proper noun (e.g. do you speak Kuuk Thaayorre?), while the term Thaayorre alone is used in adjectival contexts (e.g. the Thaayorre word for 'language' is ' $k u u k$ ') and as a label for the ethnic group.
} 
Peninsula, Australia. Of approximately 350 ethnic Thaayorre, circa 200 are regular speak$\mathrm{ers}^{2}$ of the language. Almost all of them are now resident in the Aboriginal Community of Pormpuraaw, originally established as an Anglican mission in 1938 (then named Edward River). Formerly hunter-gatherers, the Thaayorre still maintain close links to their traditional lands, mostly inland and to the south of Pormpuraaw, and many live part of the year on outstations on these lands. Around 200 speakers of the Kugu Nganhcara group of patrilects (Smith and Johnson, 2000) are also resident in Pormpuraaw. ${ }^{3}$ Although their languages are not closely related, the two groups have traditionally occupied contiguous territory, and a significant level of contact throughout history is inferred from numerous mutual loan words and calques.

The inventory of Thaayorre human body part terms is particularly noteworthy with respect to the associations made between body parts lexicalised in compound terms. Further, the majority of Thaayorre body part terms have extended functions, for instance in the description of parts of non-human entities, kinship relations, emotion, time and space. Understanding the Thaayorre conceptualisation of the body and parts thereof is therefore crucial to an understanding of how the Thaayorre conceptualise the world around them and place themselves within it.

The present study is primarily based on data collected by the author during three field trips carried out between 2002 and 2004, supplemented in places by the work of Foote and Hall (1992). Elicitation of human body part terms and their extensional and intensional ranges was conducted in accordance with the guide developed by Enfield (this volumea). This article is structured as follows: Section 2 describes the morphology of body part terms, exploring the semantic associations made between compound terms and the unanalysable terms from which they are derived. The morphological processes and semantic motivations that underlie the original creation of these terms are also explored here. Section 3 turns to semantics, to consider what counts linguistically as a body part in Kuuk Thaayorre, exploring how these parts relate to each other and to the whole they compose. Section 4 presents the inventory of human body part terms elicited, along with discussion of terms that diverge significantly from their closest English translation. The scope of investigation is broadened in Section 5 to consider terms for the parts of animals. Finally, Section 6 briefly considers some more extended uses of body part terms.

\section{Simplex and complex body part terms}

Throughout the present article, I distinguish between simplex (unanalysable, monolexemic) and complex (analysable, polylexemic) terms ${ }^{4}$ as outlined in the introduction to this

\footnotetext{
${ }^{2}$ Owing to the difficulty in assessing linguistic competence as a non-native speaker, I estimate number of speakers according to how many people preferentially use Kuuk Thaayorre in their normal daily interactions.

${ }_{3}$ The moribund language Yir-Yoront (Alpher, 1992) is also remembered (though rarely, if ever, spoken) by a few residents of Pormpuraaw, most of whom are Kuuk Thaayorre speakers.

${ }^{4}$ For the data at hand, these terms generally correspond to the 'primary' and 'secondary' lexemes of Brown (1976, pp. 402-403), who borrows the terms from Berlin et al.'s (1966) description of folk biological taxonomies. These labels entail, however, that the secondary lexeme (e.g. pungk-paant 'kneecap, lit. knee-head') morphologically incorporates the primary lexeme (i.e. pungk 'knee') of which it is a part. However, this is not always clear for Kuuk Thaayorre, nor is it a necessary feature of analysable body part terms cross-linguistically.
} 
volume (Enfield et al., this volume). The distinction is purely formal; no claims are made as to its semantic import as there is no clear correlation between morphological complexity and semantic complexity in Thaayorre body part terminology. For instance, the analysable term koow-miing 'face' is certainly more widely known, commonly used, and learnt earlier by children than the unanalysable term penprr 'side of torso extending from armpit to hip'. As Anderson (1978, p. 354) notes: 'basic [our 'simplex'] terms are frequently polysemous and often provide the source for derived [our 'complex'] terms referring to other body-parts ... based either on structural similarity or on spatial contiguity". This is both a pervasive and productive feature of Kuuk Thaayorre body part terminology.

Most commonly, Thaayorre body part compounds are derived from two simplex body part terms. The semantic schemata underlying some of these combinations are cross-linguistically common (compare, e.g., Wilkins, 1996; Heine, 1997), such as paant-thuur (head-marrow) 'brain', and pungk-paant (knee-head) 'kneecap'. Others are more unusual, such as thamur-thip (foot-liver) 'sole of foot'. Interestingly, the Thaayorre term meerpaath-wirm (eye-fire-WIRM) 'pupil', contains the same pupil/flame metaphor as does the Welsh pupil term, which translates literally as 'candle of the eye' (see Heine, 1997, p. 132; Brown and Witkowksi, 1981, p. 600) - a metaphor nowhere else attested in Brown and Witkowski's sample of 118 languages.

Overwhelmingly, in Kuuk Thaayorre, the denotatum of the first element of a complex term is related to the denotatum of the entire term by spatial contiguity and/or inclusion, while the denotatum of the second element is related via some physiological similarity, in terms of form, function or structure. So meer-pungk 'eyebrow' is metonymically located above the meer 'eye', and resembles the pungk 'knee' in its arched shape and position above an active body part.' Yuur-mut 'back of hand' is related to the yuur 'hand' by synecdoche, and the mut 'back' by virtue of its being the inactive side, with a prominent bone structure that stabilises its superordinate part (i.e. the hand or torso). It should be noted that the second element of these complex terms is not always a body part term. It may be a 'cranberry' morpheme (as in pil-perrk 'hipbone', lit. 'hip-PERRK') or a noun/adjective from the broader Thaayorre vocabulary (as in man-werngr 'collarbone', lit. 'throat-boomerang' or yuur-ngamal 'thumb', lit. 'hand-big'). Body part compounds may also be derived from more than two simplex terms, as in koo-mut-panjr ' 'moustache' (lit. 'nose-back-body.hair') and ngeengk-kun-ngamal 'stomach, bowel' (lit. 'belly-bum-large'). For the former, two sequential processes of derivation are indicated. The first involves koow 'nose' and mut 'back' being compounded to form koo-mut 'upper lip'. This output then feeds into the new compound koo-mut ('upper lip') + panjr ('body hair') > koo-mut-panjr 'moustache'. The etymology of ngeengk-kun-ngamal 'stomach, bowel' is unknown at this stage.

These constructions deriving Thaayorre body part terms are not without analogues of a more general nature. Firstly, complex body part lexemes resemble the generic-specific couplings found frequently throughout the language (and across the Australian continentsee Dixon, 1980). Here, the generic-specific construction as a whole is a hyponym of its first element:

\footnotetext{
5 As mentioned in Section 4.2, yangkar 'calf' is viewed as the active body part involved in walking.

${ }^{6}$ Word-final glides are usually deleted when part lexemes (notably koow 'nose' and thaaw 'mouth') appear as the initial component of a compound. This appears to be a purely morphophonological process.
} 


$\begin{array}{lll}\text { (1) } \begin{array}{ll}\text { minh } \\ \text { animal } \\ \text { 'wallaby' }\end{array} & \begin{array}{l}\text { kothon } \\ \text { wallaby }\end{array} \\ \text { (2) } & \begin{array}{l}\text { ngok } \\ \text { water }\end{array} & \text { paapath } \\ & \text { RDP:fire }\end{array}$

Example (2) in particular resembles complex body parts such as yuur-mant 'finger" (lit. 'hand-small'). In both, the first element represents the more general entity with which the expression is associated, while the second specifies the defining characteristic of the complex term/construction. However, while the body part compounds involve either meronymic or metonymic linkage (the denotatum of the compound is a part of the denotatum of its first element, or more generally associated with it), the generic specific pairing is a hyponym (a type) of its first element. That is to say, yuur-mant 'finger' is associated with the yuur 'hand', but is not a type of yuur 'hand'. If yuur-mant 'finger' (lit. 'hand-small') were related to yuur 'hand' in the same way as ngok paapath 'liquor' (lit. 'water RDP:fire') is related to ngok 'water', yuur-mant 'finger' should be considered a 'small hand' rather than a 'small [part] of the hand'. Although the 'small hand' interpretation may seem (marginally) plausible, it is clearly not applicable to yuur-ngamal 'thumb' (lit. 'hand-big'), as a thumb could not be considered a big hand. Rather, yuur-mant and yuur-ngamal can best be understood as referring to a 'small one of the hand' and a 'large one of the hand' respectively. Thus it is the second element of a body part compound that constitutes the semantic head, whereas the semantic head of a generic-specific pairing is the first element. Furthermore, impressionistic evidence suggests that the complex body part term yuur-mant 'finger' is prosodically differentiated from the productive coupling yuur mant 'small hand'.

The second analogous construction (suggested by the translation 'small one of the hand') is the inalienable possession/part-whole construction. ${ }^{9}$ Semantically very close to the body part compounds, this construction apposes two partonomically related lexemes in the same case. ${ }^{10}$ An example of this is:

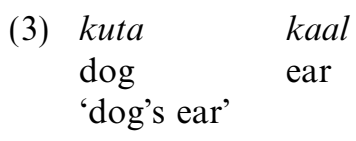

\footnotetext{
${ }^{7}$ It is important to note here that, in Kuuk Thaayorre, the distinction between nouns and adjectives is not clearcut. Many lexemes (such as mant 'small (one)' and paapath 'hot (one)') may function either as (adjective-like) modifier and (noun-like) head, depending on their position in the noun phrase.

${ }^{8}$ As noted above, it is this difference in prosody, as well as the ungrammaticality of other morphemes or lexemes intervening between the terms, that suggests that analysable body part terms are compounded, rather than merely juxtaposed.

${ }^{9}$ Similar constructions have also been labelled 'external possession' (see, for example, the papers in Payne and Barshi, 1999) or described in terms of 'possessor raising'. I do not find this useful in describing the Thaayorre data, since (as Blake, 1990, p. 102, has pointed out for other Australian languages) there is no reason to view the inalienable construction as derived from a (more basic) underlying construction in which the possessor is realised as a genitive NP.

${ }^{10}$ Note that in example (3), part and whole are in unmarked nominative case.
} 
Complex body part compounds are distinguished from this inalienable construction by prosody, the ungrammaticality of intervening morphemes or lexemes (in the case of compounds), and sometimes phonological reduction. Comparing the structure of complex body part terms with more general constructions aids our understanding of body part compounds and suggests a possible diachronic source for them. ${ }^{11}$ The grammaticalisation of body part terms from such inalienable pairings is likely to follow the pattern presented in (4), with (4a) representing a hypothetical earlier stage and (4b) the synchronic compound term:

$\begin{array}{ll}\text { (4a) } \begin{array}{l}\text { meer panjr } \\ \text { eye body.hair }\end{array} & >\text { (b) } \begin{array}{l}\text { meer-panjr } \\ \text { eye-body.hair } \\ \text { 'eye's hairs' }\end{array}\end{array}$

I speculate that this process must have already become productive by the time compounds such as kaal-thamr 'earlobe' (lit. 'ear-foot') were coined, as the latter would require a prior step of metaphoric association. This is because an ear does not have a foot (if, as I propose, we take thamr 'foot' to refer literally to the body part at the end of the leg) in the same way that an eye has hairs.

In compounds denoting 'bodily products' or excreta, the first element serves to denote the source of the product. So, in meer-ngok 'tear' (lit. 'eye-water'), meer 'eye' represents the point of origin of the tear, rather than entering into a metonymic or synechdochic relationship with it. This derivational process is still productive, and extends to the description of emissions from parts of inanimate objects, as in (5):

\section{(5) ngul minj nhaawr jet kun-thomp-kaak yanj-im \\ then really saw jet bum-smoke-PROP go-IPF \\ 'then we saw a jet going along with smoke coming out behind it'}

Here kun-thomp (lit. 'bum-smoke') specifies the point of origin of the vapour trail seen by the story's protagonists.

Excreta can also be encoded via conventionalised lexical ambiguity. So, for example, kun means either a 'bum' or 'faeces', while theler can refer to a 'womb' or 'placenta'. Each of these encodes an association between the source ('bum' or 'womb') and the product ('faeces' or 'placenta'). ${ }^{12}$ This is just one example of conventionalised metonymic extension, a process exploited throughout Thaayorre vocabulary (as well as those of many Australian languages). While terms for excreta are based on source/product metonymy, examples from other semantic domains are typically based on other kinds of association. Paath, which may mean both 'firewood' and 'fire', makes use of the actual/potential

\footnotetext{
11 Since there is no fixed order of possessor and possessum in this construction (nor are they required even to be adjacent), there would need to be some mediating stage in which the possessor immediately preceded the possessum prior to the creation of body part compounds.

${ }^{12}$ Burenhult (this volume) documents similar source/product ambiguity in Jahai.
} 
metonymy described by Evans (1992). Similarly, the ambiguous may puun 'honey' or 'bee', is an example of item/index ${ }^{13}$ metonymy.

\section{Segmenting 'the body'}

\subsection{Parts of a whole?}

Before presenting an inventory of body part terminology in Section 4, it is necessary first to delimit the scope of enquiry. In English, the term body provides a relatively unproblematic starting point: the physical manifestation of a person. In Kuuk Thaayorre, however, it is less simple to determine what entity it is that 'body parts' form part of. The Thaayorre lexeme with the closest extensional range to the English body is pam-minj (literally, 'true man'), which may be used to refer to the specifically physical presence of a human (including that purely physical human entity, the corpse). However, pam-minj also includes in its scope many non-corporeal components of a living person (e.g. their tracks, voice, shadow, etc.). Since the terms denoting these non-corporeal human parts appear in morphosyntactic constructions reserved for parts of the body, there is good reason to consider them alongside the more traditional hand, head, leg, etc. So, for instance, koow 'nose' in (6), and man-nganp 'shadow' (lit. 'throat-NGANP') in (7), are apposed to the pronoun representing the whole person in the same case, ${ }^{14}$ thus establishing coreference:

$\begin{array}{llll}\text { koow } & \text { rathirr } & \text { peln } & \text { nhunh } \\ \text { nose(ACC) } & \text { chop:PERF } & \text { 3pl(ERG) } & \text { 3sgACC } \\ \text { 'they chopped off his nose' }\end{array}$

(7)

$\begin{array}{llll}\text { nhul } & \text { nganh } & \text { nhaawr } & \text { man-nganp } \\ \text { 3sg(ERG) } & \text { 1sgACC } & \text { saw } & \text { shadow(ACC) } \\ \text { 'he saw my shadow' } & & \end{array}$

This construction is not available to inalienable possessions other than parts of the body. For instance, it is not possible to say:

*kuta-ku parr.rpatharr $\quad$ nganh
dog-ERG child bite:PERF
'the dog bit my child'

Similarly, reflexivisation, reciprocalisation and other derivational processes treat non-corporeal aspects of humans in the same way as more traditionally conceived body parts. This indicates the existence in Kuuk Thaayorre of a category somewhat broader than that of

\footnotetext{
${ }^{13}$ While 'bee' could be alternatively characterised as the source of its product 'honey', the fact that the term may puun involves the generic noun may 'vegetable food' (in place of the 'insect' generic noun ruurr expected for 'bee') suggests that the 'honey' sense is historically prior. This in turn suggests that bees came to be referred to by the 'honey' term due to their being a good index of the prized honey's location. The converse use of animal terms to refer to plants that index the animal's presence in other Australian languages is documented by Evans (1997).

${ }^{14}$ See also Hale (1981), McGregor (1985) and McGregor (1999) for discussion of the analogous 'favourite construction' in Warlpiri, Gooniyandi and Nyulnyulan languages respectively.
} 
'body parts' (in its including non-corporeal human parts) but yet narrower than 'inalienable possession' (i.e. excluding kin terms, etc.). ${ }^{15}$ This paper, while ostensibly concerned only with 'body parts', will reflect the inclusiveness of this Thaayorre category by treating corporeal and non-corporeal 'person parts' as equivalent.

As its literal translation suggests, pam-minj 'true man' further differs from English body in its intensional opposition to non-human things, in contrast with body's opposition to non-physical things. ${ }^{16}$ This can make it somewhat difficult to articulate a mind/body distinction in Kuuk Thaayorre. Consequently, when I asked three Thaayorre speakers to describe a man who was physically very old and sick, but mentally agile, they were initially at a loss. One speaker eventually formulated the sentence in (9) (employing the compound minj-thaaw (lit. 'true-mouth'), which is seldom used with the meaning 'body'), while the other two relied upon terminology borrowed from English, (10):

\section{minj-thaaw minj-wanj-aak,} true-mouth true-ache-PROP '(his) body is sick, but his mind is good'

\section{mind wuump kana \\ mind CNTR good}

kana

good

'sgNOM body bad mind CNTR
'his body is sick, but his mind is good'

According to these consultants, it would not be appropriate to use pam-minj (the more usual term for 'body') in this context. Clearly, the boundary between a human's physical and non-physical aspects (e.g. mind, voice or footprints) is not as salient in Kuuk Thaayorre as it is in English. Accordingly, the label 'body part term' will be applied throughout this paper quite loosely to any lexeme entering a part-whole relationship with a human as defined by Thaayorre language-internal morphosyntactic and semantic criteria.

\subsection{Parts of parts}

Having defined the domain of investigation, the next step is to analyse the relationship of parts of the body (or parts of the person) to each other. One may reasonably wish to begin with a partonomy, a division of the body into parts of parts. Methodologically, though, this task is complicated in Kuuk Thaayorre by the apparent lack of an expression corresponding to part of. ${ }^{17}$ Neither elicitation nor observation have yet revealed a strategy for explicitly commenting on a part-whole relationship (either with respect to the human body or other objects in the world). Note that this runs counter to Wierzbicka's (1994, p. 489) proposition that the relational concept part of is a (universally lexicalised) semantic primitive. Further

\footnotetext{
15 Both Nichols (1988) and Chappell and McGregor (1996) show that the slippery category of 'inalienability' cannot be predictably applied cross-linguistically.

${ }^{16}$ This is evidenced in the common English collocations body and mind or body and soul. See also Evans and Wilkins (2001, p. 512) for a discussion of how the simple term for 'man' (i.e. pam and its cognates) is similarly used in many Australian languages in opposition to ancestral beings.

${ }^{17}$ Kuuk Thaayorre is by no means the only language to lack such an expression. Compare, for example, Meira (this volume) on Tiriyó.
} 
research may reveal that this concept is, in fact, grammaticised in Kuuk Thaayorre. However, the fact remains that, when asked to define or describe a body part, ${ }^{18}$ consultants never invoked partonomic relationships. Indeed, consultants have not explicitly made reference to part-whole relationships in the description of entities in any semantic domain ${ }^{19}$ (e.g. parts of a traditional hut, parts of a spear, or parts of a song). To date the best candidates for more obliquely expressing a partonomic relationship are as follows: (a) the proprietive construction; (b) the alienable possessive construction; (c) the inalienable possessive construction. A discussion of the limitations of each of these frames follows.

The proprietive construction (seen in example (11)) proved the most fruitful elicitation frame. Here the proprietive morpheme $=k a a k$ is encliticised to the second element, marking it as the subordinate partonym: ${ }^{20}$

$\begin{array}{lll}\text { ?koo.miing } & \text { meer } & \text { kuthirr = kaak } \\ \text { face } & \text { eye } & \text { two = PROP }\end{array}$

'a face has two eyes'

?paant meer kuthirr= kaak
head eye two = PROP
'a head has two eyes'

?pam.minj $\quad$ meer
bodythirr= kaak
'a body has two eyes'

While the proprietive construction in (11-13) appears to be a suitable vehicle for encoding (and thereby revealing) part-whole relationships within the Thaayorre body partonomy, it might more generally function to encode relationships such as metonymy, synechdoche, etc. (expressing in (11), for example, that the eyes are located on the face, rather than necessarily being a constituent part of the face). Bearing this caveat in mind, we might expect the proprietive construction to be useful in testing the "transitivity' ${ }^{21}$ of the human partonomy. However, although it appears prima facie to constitute a more promising test of partonomy than the use of alienable and inalienable possession constructions (see below), the use of the proprietive enclitic to describe such relationships between parts is acceptable only to a minority of speakers. Its usefulness in constructing and evaluating a human partonomy is therefore severely limited.

\footnotetext{
${ }^{18}$ Consultants were prompted in this regard in a number of ways: (a) by asking inhul ngan? 'what is this one' (accompanied by a point to a body part); by asking, e.g. punth ngan? 'what is a punth (arm)?'; (c) by asking punth kar ngan? 'what is a punth (arm) like?'; and (d) by playing games where one consultant had to describe a body part until another consultant could guess which part they were talking about.

${ }^{19}$ Taxonomic relationships, too, are expressed by the simple juxtaposition of hyponym and superordinate term, and consultants have not yet provided an explicit description of a 'kind of' relationship.

${ }^{20}$ Note that enclitics always occur phrase-finally in Kuuk Thaayorre, so =kaak is found encliticised to the quantifier kuthirr 'two' rather than its head meer 'eye' in examples (11-13).

${ }^{21}$ Transitivity is a characteristic typically associated with taxonomies, stated simply: if $\mathrm{x}$ is a hyponym of $\mathrm{y}$ and $\mathrm{y}$ is a hyponym of $\mathrm{z}$, then $\mathrm{x}$ is also a hyponym of $\mathrm{z}$. The question of whether this principle applies equally to partonomies is addressed by McClure (1975), Brown (1976, p. 407) and Winston et al. (1987).
} 
The alienable possession construction is another candidate for expressing part-whole relationships. ${ }^{22}$ Here the possessor NP is marked for genitive case and the possessum is unmarked:

kuta pam-ak
dog man-GEN
'the man's dog' or 'the dog is of the man'
thamr-rirkr thamr-ak
foot-shell foot-GEN
'a toenail is of the foot'

There are two clear limitations of this construction. Firstly, the genitive suffix is homophonous with the locative case suffix for many nouns, as a comparison of (15) with (16) demonstrates:

$$
\begin{aligned}
& \text { thamr-put thamr-ak } \\
& \text { foot-shoe foot-LOC } \\
& \text { 'a shoe is on the foot' }
\end{aligned}
$$

There is thus a very real danger that questioning the truth content of clauses like (15) would provoke an analysis of spatial contiguity, rather than partonomic compositionality.

The second drawback is that in a language with a grammaticised alienable-inalienable distinction, the hearer would expect the relationship between a body part and its subpart to be referred to by means of an inalienable construction. Using the alienable construction in its place is therefore pragmatically marked, encoding an informationally weaker relationship between possessum and possessor than actually holds (cf. Levinson, 2000). Not surprisingly, therefore, Thaayorre consultants tend to offer inconsistent judgements when prompted with alienable constructions.

Regrettably, the inalienable possession construction is even less useful in establishing partonomic relationships than the alienable construction. The difficulty this time lies in the necessity, when relating sub-part to part, of bringing into the construction multiple exponents of the same body part ${ }^{23}$ (e.g. pungk 'knee' in (17)). To do so sounds distinctly odd, if not ungrammatical:

$$
\begin{aligned}
& \begin{array}{l}
\text { *pungk pungk-paant } \\
\text { knee } \\
\text { 'a knee-head }
\end{array} \\
& \text { 'a knee-cap's }
\end{aligned}
$$

In the majority of complex body part terms, the denotatum of the compound term falls within the physical boundary of the denotatum of the compound's first element (i.e. a pungk-paant 'kneecap' fits within the boundaries of the pungk 'knee'). But as these complex

\footnotetext{
${ }^{22}$ Note that although the relationship between the toenail and foot is used to exemplify the alienable possession construction, this relationship could equally well be expressed by the inalienable or proprietive constructions.

${ }^{23}$ As demonstrated in Section 2, the apposition of unmarked possessor and inalienable possessum is a candidate bridging context for (and is almost identical with) the complex, polymorphemic body part terms.
} 
terms are synchronically nominal compounds (not productive inalienable constructions), this does not a priori correlate with a partonomic relationship between the two denotata. For instance, some speakers are comfortable with the assertion:

$$
\begin{aligned}
& \text { ?thaaw man-theepr }=\text { kaak } \\
& \text { mouth throat-tongue-PROP } \\
& \text { 'a mouth has a tongue' }
\end{aligned}
$$

Since there is no evidence of a hyponymic relationship between man 'throat' and thaaw 'mouth', man 'throat' cannot be assumed to be a hypernym of man-theepr 'tongue' merely because it is the first element of the latter. The relationship between the complex term and the lexemes from which it is formed is rather one of more general association.

From the preceding discussion, it is clear that satisfactory linguistic means for eliciting a Thaayorre body partonomy have not yet been forthcoming. However, a partonomy is not the only possible system of body part organisation. Palmer and Nicodemus (1985), for instance, discuss systems of body parts grouped with respect to spatial relations in Coeur $\mathrm{d}^{\prime}$ Alene ${ }^{24}$. With this in mind, we note that Thaayorre speakers' descriptions of body parts (elicited as described above) are also sometimes based on spatial relations, as in (19):

$$
\begin{aligned}
& \text { yuur punth-an } \\
& \text { hand arm-LOC } \\
& \text { 'the hand is at/on the arm' }
\end{aligned}
$$

More commonly, however, consultants describe parts with respect to their function, as in (20) and (21), rather than by appealing to their location:

nhunt nhaanham meer-e
2 sgERG look eye-ERG
'you see with your eyes'

(21) thamr yenj-nhata

foot go-DESID

'a foot is for walking'

\section{Inventory of terms}

Section 4 presents the inventory of Thaayorre body part terms collected to date, in the form of tables grouped according to (4.1) parts of the face; (4.2) external (or visible) parts

\footnotetext{
${ }^{24}$ See also papers on Lao (Enfield, this volume-b), Punjabi (Majid, this volume) for other examples of spatial relations between body parts.
} 
of the body; (4.3) internal parts of the body; and (4.4) other parts of the body (including excreta, growths, bodily products and parts defined by their configuration). The leftmost column presents the Thaayorre body part term. Next, translations of body part terms are given in plain English. In many cases, the extensional range of the Thaayorre term does not match that of its English translation. Any large discrepancies between term and translation are explicated in the text. The final column gives a morpheme-by-morpheme gloss; unanalysable 'cranberry' morphemes (forms that are not found outside that compound), are glossed by the Thaayorre form in capitals. ${ }^{25}$

\subsection{Face and its parts}

Kuuk Thaayorre is unusual in not having a simplex label for the face. ${ }^{26}$ The term koomiing 'face' is formed by compounding koow 'nose' with miing 'daytime'. Comparison with cognate kaa 'upper face' in Kugu Nganhcara (Smith and Johnson, 2000, p. 445), suggests that the Thaayorre term koow 'nose' may have narrowed in its meaning, the compound koo-miing perhaps being formed at a time when koow meant 'upper face'. See below for further discussion of the diachronic development of this term.

Table 1 presents the Thaayorre terms for parts of the body falling within the area denoted by koo-miing 'face'. Discussion of some of the more problematic terms follows.

There is some intergenerational variation in the labelling of the lips. Very elderly speakers consistently differentiate the two lips; koo-petan 'upper lip' (lit. 'nose-skin') and thaapetan 'lower lip' (lit. 'mouth-skin'). This may follow from an earlier stage at which koow (now 'nose') referred to the upper half of the face and thaaw (now 'mouth') the lower, cf. Kugu Nganhcara kaa 'upper face' and thaa 'lower face' (Smith and Johnson, 2000, p. 445). For today's children, however, thaa-petan (lit. 'mouth-skin') refers equally to both lips. When asked what they think koo-petan (lit. 'nose-skin') might mean, most children guess that it would refer to the area between the nose and the mouth (also ambiguously termed upper lip in English). This coincides with their having failed to acquire the Thaayorre term for this body part, koo-mut (lit. 'nose-back').

The lexeme therprr has also undergone a semantic shift. Formerly denoting the chin alone (hence applying equally to men and women), it has come to include hair on the chin - while still retaining the original chin sense - for most middle-aged to older speakers. Today's children, however, understand therprr to refer only to a beard or moustache or both, and do not accept it as being applicable to women. Interestingly, one consultant in his fifties also used therprr to refer to the lower lip, in the utterance:

therprr kana mat
chin PERF dry
'my lip is dry (I'm thirsty)' [pointing to lower lip]

\footnotetext{
${ }^{25}$ Where the semantic contribution of a bound morpheme is clear (e.g. where it also occurs outside of body part compounds), it is glossed with an approximate translation, rather than the Thaayorre form in capitals. For instance, the bound morpheme ruuw 'front' (found in the compound man-ruuw 'chest') never occurs in isolation, however, its meaning can be gleaned from some other contexts in which it appears, such as the compound ruuwan-kanpa 'in front of' (lit. 'front:LOC-before').

${ }^{26}$ Cf. Brown's (1976, p. 404) claim that "all parta at Level 1 are labelled by primary lexemes".
} 
Table 1

Parts of the face

\begin{tabular}{|c|c|c|}
\hline Thaayorre term & Translation & Gloss \\
\hline \multicolumn{3}{|l|}{ Simplex } \\
\hline koow & 'nose' & 'nose' \\
\hline meer & 'eye’ & 'eye’ \\
\hline thaaw & 'mouth' & 'mouth' \\
\hline therprr* & 'chin' & 'chin' \\
\hline \multicolumn{3}{|l|}{ Complex } \\
\hline koo-miing & 'face' & 'nose-daytime' \\
\hline koo-mut & 'overlip' (area between mouth and nose) & 'nose-back' \\
\hline koo-mut-panjr & 'moustache' & 'nose-back-body.hair' \\
\hline koo-petan & 'upper lip' & 'nose-skin' \\
\hline koo-ranth & 'nostril' & 'nose-hole' \\
\hline koo-rirkr & 'forehead' & 'nose-shell' \\
\hline koo-thongkn & 'nose-bone' & 'nose-log' \\
\hline meer-mut & 'eyelid’ & 'eye-back' \\
\hline meer-nhapn & 'eyeball' & ‘eye-egg’ \\
\hline meer-paath-wirm & 'pupil' (Foote and Hall, 1992, p. 231) & 'eye-fire-WIRM' \\
\hline meer-panjr & ‘eyelash’ & 'eye-body.hair' \\
\hline meer-piinth & 'cheekbone' & 'eye-bone' \\
\hline meer-pungk & 'eyebrow' & 'eye-knee’ \\
\hline meer-wal & 'area on the outerside of eyes' & 'eye-temple' \\
\hline paant-wal & 'temple' & 'head-temple' \\
\hline thaa-petan & 'lower lip' (this term is ambiguous, also meaning 'labia') & 'mouth-skin' \\
\hline thaa-put & 'cheek' & 'mouth-PUT' \\
\hline wal-kut & ‘jaw’ & 'temple-KUT' \\
\hline
\end{tabular}

The consultant then went on to stress that he was talking about his lower lip, not his beard, making clear that he was aware of the potential confusion arising from this ambiguity. None of the other speakers consulted, however, described the lower lip as therprr.

\subsection{External parts}

Function appears to be at the semantic core of many terms for external parts of the body. For instance, the term nhit 'area above hip' is commonly described by native speakers as the place where young children are carried. Similarly, regions such as kap 'area under arm'; man-pert 'shoulder ridge'; and mepr-rirkr 'shoulder blade' are likely lexicalised because they are the places where many items of material culture are carried (and accordingly consultants often make reference to coolamons, bags or other transported items in describing these parts). Function is also at the core of the term yangkar 'calf', viewed as the active body part involved in walking in the absence of a general term for 'leg'.

The inventory of external body part terms collected so far is given in Table 2 .

The referentially unusual term may-pungk 'fleshy hip area' seems to be used primarily with reference to animals (its lexicalisation no doubt connected to intended consumption), and is only marginally applicable to the human body.

The term penprr 'side of body' may be used with either a narrow or broad reference. In its narrow reference (e.g. if a consultant is asked to colour penprr on a picture of the human body), it denotes the side of the torso between the armpit and the hip. However, it may be used more broadly in contexts such as the following: 
Table 2

External parts of the body

\begin{tabular}{|c|c|c|}
\hline Thaayorre term & Translation & Gloss \\
\hline \multicolumn{3}{|l|}{ Simplex } \\
\hline kaal & 'ear' & 'ear' \\
\hline kap & 'underarm' & 'underarm' \\
\hline kumun & 'thigh' & 'thigh' \\
\hline kun & 'bum' & 'bum' \\
\hline kunj & 'penis' & 'penis' \\
\hline man & 'throat' & 'throat' \\
\hline mepr & 'corner of shoulder' & 'corner.of.shoulder' \\
\hline mut & 'back' & 'back' \\
\hline ngeengk & 'belly' & 'belly' \\
\hline ngutr & 'navel' & 'navel' \\
\hline nhit & 'area above hip' & 'above.hip' \\
\hline paant & 'head' & 'head' \\
\hline panjr & 'body hair' & 'body.hair' \\
\hline penprr & 'side of body' & 'armpit.to.hip' \\
\hline petan & ‘skin’ & 'skin’ \\
\hline pil & 'hip' & 'hip’ \\
\hline pungk & 'knee' & 'knee' \\
\hline punt & 'elbow’ & 'elbow' \\
\hline punth & 'arm' & 'arm' \\
\hline rerngk & 'torso' (Foote and Hall, 1992, p. 132) & 'torso' \\
\hline riila & 'testicle' & 'testicle' \\
\hline thaathin & 'breast' & 'breast' \\
\hline thamr & 'foot' & 'foot' \\
\hline yangkar & 'calf' & 'calf' \\
\hline yangn & 'head hair' & 'head.hair' \\
\hline yin & 'female sex organ' & 'female.sex.organ' \\
\hline yuur & 'hand' & 'hand' \\
\hline \multicolumn{3}{|l|}{ Complex } \\
\hline kaal-ranth & 'ear-hole' & 'ear-hole' \\
\hline kaal-thamr & 'earlobe' & 'ear-foot' \\
\hline kaap-ranth & 'armpit' & 'underarm-hole' \\
\hline kun-thaaw & 'anus (external)' & 'bum-mouth' \\
\hline man-pert & 'shoulder ridge' & 'throat-PERT' \\
\hline man-ruuw & 'chest (male)' & 'throat-front' \\
\hline man-werngr & 'collarbone' & 'throat-boomerang' \\
\hline mangk-nherp & 'waist' (Foote and Hall, 1992, p. 79) & 'middle-spirit' \\
\hline may-pungk & 'fleshy hip area' & 'vegetable.food-knee' \\
\hline mepr-rirkr & 'shoulder blade' & 'corner.of.shoulder-shell' \\
\hline mut-mangk & 'centre of back' & 'back-middle' \\
\hline pungk-paant & 'kneecap' & 'knee-head' \\
\hline pungk-rathilk & 'hollow behind knee' (Foote and Hall, 1992, p. 115) & 'knee-RATHILK' \\
\hline pungk-therrep & 'kneecap' & 'knee-rock' \\
\hline punt-man-aakr & 'soft area inside elbow' & 'elbow-throat-AAKR' \\
\hline punth-kun-mangk & 'upper arm' & 'arm-bum-middle' \\
\hline punth-man-koow & 'forearm' & 'arm-throat-nose' \\
\hline thaa-man-aakr & 'soft area under chin' & 'mouth-throat-AAKR' \\
\hline thaa-petan & 'labia’ (also ‘lip’) & 'mouth-skin' \\
\hline thaathin-meer & 'nipple' & 'breast-eye' \\
\hline thamr-(koo-)ngamal & 'big toe' & 'foot-(nose-)big' \\
\hline thamr-mant & 'toe' & $\begin{array}{l}\text { 'foot-small' } \\
\text { (continued on next page) }\end{array}$ \\
\hline
\end{tabular}


Table 2 (continued)

\begin{tabular}{lll}
\hline Thaayorre term & Translation & Gloss \\
\hline thamr-mut & 'upper side of foot' & 'foot-back' \\
thamr-rathr & 'ankle' & 'foot-RATHR' \\
thamr-rirkr & 'toenail' & 'foot-shell' \\
thamr-thip & 'sole of foot' & 'foot-liver' \\
thamr-wuurr & 'toe' & 'foot-digit' \\
yuur-(koo-)ngamal & 'thumb' & 'hand-(nose-)big' \\
yuur-mant & '(pinkie) finger' & 'hand-small' \\
yuur-mut & 'back of hand' & 'hand-back' \\
yuur-pil & 'wrist' & 'hand-hip' \\
yuur-rirkr & 'fingernail' & 'hand-shell' \\
yuur-thip & 'palm of hand' & 'hand-liver' \\
yuur-wuurr & 'finger' & 'hand-digit'
\end{tabular}
parr_r ngeey ongkorr penprr wun! child:NOM listen:IMPER PROHIB side lie:IMPER

'Child, don't lie on your side!'

The ambiguous term thamr-rathr may refer to either the 'ankle' or the noise of 'footfall'. While the first element thamr 'foot' is clearly related to the former sense by contiguity, and the latter by being the source or cause of the noise, the semantic contribution of the second element, rathr, is less transparent. The form rathr is both a verb, meaning 'chop', and a noun, meaning 'sharp noise' (e.g. the bang of a door closing). The latter meaning seems likely related to the 'footfall' sense of thamr-rathr as both refer to the kinds of noise created by collision (the collision between foot and ground, in the case of thamrrathr 'footfall'). The verbal 'chop' sense may be related to 'footfall' through their both describing an iterated series of abrupt contacts. ${ }^{27}$ There may be some commonality between the 'ankle' sense of thamr-rathr and the semantics of 'chop' (the ankle being a point of cleavage between the foot and the leg), however, consulted speakers were reluctant to ponder the etymology of these terms, which appear to be synchronically unanalysable.

There is some ideolectal variation in the extensional range of digit terms, much as Burenhult (this issue) reports for Jahai. While all consultants agree that yuur-ngamal (lit. 'hand-big') refers to the 'thumb' and thamr-ngamal (lit. 'foot-big') the 'big toe', speakers vary as to how they label other digits. Some refer to all the fingers as yuur-mant (lit. 'hand-small') and all the toes as thamr-mant (lit. 'foot-small'), while others use these terms only to refer to the 'pinkie (i.e. smallest) finger' and 'pinkie toe' respectively. When the latter group of speakers were asked how they would refer to the middle finger, some were at a loss, while one stated that yuur-ngamal (lit. 'hand-big') could refer to any finger but the littlest. The term yuur-wuurr (lit. 'hand-digit') 'finger', by contrast, may be used to refer to any of the fingers (and for some speakers the thumb), and thamr-wuurr (lit. 'foot-digit') any toe. Wuurr 'digit', however, appears to be somewhat antiquated, and is only used regularly by elderly speakers (but recognised by most adult speakers). Accordingly, yuur-wuurr (lit. 'hand-digit') is being superseded by yuur-mant (lit. 'hand-small'), presumably by analogy (or, rather, in contrast) with yuur-ngamal (lit. 'hand-big').

\footnotetext{
27 This semantic link was pointed out by an anonymous reviewer.
} 


\subsection{Internal parts}

As with external parts of the body, internal body parts may either be discrete and welldefined (as with ngeengk-thip 'liver') or they may be distributed (as with rithrr 'fat') (Table 3). Parts such as kiin 'tooth, gum', meer-piinth 'cheekbone', and theler 'womb, placenta' are for the most part internal to the body, but are either visible through the skin or may

Table 3

Internal parts of the body

\begin{tabular}{|c|c|c|}
\hline Thaayorre term & Translation & Gloss \\
\hline \multicolumn{3}{|l|}{ Simplex } \\
\hline kiin & 'tooth, gums' & 'teeth' \\
\hline man & 'throat' & 'throat' \\
\hline ngeengk & 'belly’ & 'belly, stomach' \\
\hline piinth & 'bone' & 'bone' \\
\hline piram & 'bladder' & 'bladder' \\
\hline pukal & 'umbilical cord' & 'umbilical.cord' \\
\hline rithrr & 'fat' & 'fat' \\
\hline thaat & 'tendon' & 'tendon' \\
\hline thawarr & 'lung' & 'lung' \\
\hline theler & 'womb, placenta' & 'womb, placenta' \\
\hline \multicolumn{3}{|l|}{ Complex } \\
\hline kermpr(-thaaw) & 'muscle' & 'muscle(-mouth)' \\
\hline kun-piinth & 'coccyx' & 'bum-bone' \\
\hline kun-ranth & 'anus (internal)' & 'bum-hole' \\
\hline kun-worngoj & 'large intestine' & 'bum-WORNGOJ' \\
\hline man-kunj & 'uvula' & 'throat-penis' \\
\hline man-ngeengk & 'heart' & 'throat-belly' \\
\hline man-pukal & 'protrusion of trachea' & 'throat-umbilical cord' \\
\hline man-theerpr & 'tongue' & 'throat-tongue' \\
\hline man-yakyakr & 'lung' & 'throat-cut:RDP' \\
\hline meer-piinth & 'cheekbone' & 'eye-bone' \\
\hline mut-riitham & 'kidney' & 'back-kidney' \\
\hline (mut-) thelel & 'spine' & '(back-)spine' \\
\hline muth-thelel & 'neck bone' & 'back.of.neck-spine' \\
\hline ngeengk-kun-ngamal & 'guts' & 'stomach-bum-big' \\
\hline ngeengk-thip & 'liver' & 'stomach-liver' \\
\hline paant-thuur & 'brain' & 'head-marrow' \\
\hline penprr-piinth & 'ribs' & 'side.from.armpit.to.hip-bone' \\
\hline piinth-thuur & 'marrow' & 'bone-marrow' \\
\hline pil-piinth & 'hip bone' & 'hip-bone' \\
\hline pil-perrk & 'hipbone' & 'hip-PERRK' \\
\hline pil-kermpr & 'thigh muscle (any)' & 'hip-muscle' \\
\hline punth-nherp & 'arm vein' & 'arm-spirit' \\
\hline punth-put & 'bicep' & 'arm-PUT' \\
\hline punth-raal & 'elbow bone' & 'arm-RAAL' \\
\hline punth-thaat & 'arm tendon' & 'arm-tendon' \\
\hline wal-kut-piinth & 'jaw bone' & 'temple-KUT-bone' (wal-kut 'jaw') \\
\hline yangkar-pan & 'calf muscle' & 'calf-PAN' \\
\hline yangkar-thaat & 'tendon in leg' & 'calf-tendon' \\
\hline yin-ranth & 'vagina (internal)' & 'female.sex.organ-hole' \\
\hline yuur-piinth & 'knuckle' & 'hand-bone' \\
\hline
\end{tabular}


become visible at some times. Other internal parts are usually visible only when animals are dissected for consumption. Ngeengk-thip 'liver' (lit. 'stomach-liver'), for instance, seems likely derived from the animal part term thip 'liver'. The application of such animal part terms to the parts of humans may be influenced by the fact that we encounter the internal organs of animals more frequently than those of humans. Such examples remind us that we cannot assume the human body part sense of polysemous morphemes to be historically prior.

Many of the terms for particular muscles or bones include unanalysable cranberry morphemes, viz pil-kermpr 'thigh muscle' (lit. 'hip-KERMPR'); yangkar-pan 'calf muscle' (lit. 'calf-PAN'); pil-perrk 'hipbone' (lit. 'hip-PERRK'); and punt-raal 'elbow bone' (lit. 'elbowRAAL'). The morpheme put in thaa-put 'cheek' and punth-put 'bicep' has no clear semantic content, but its appearance in the compounds put-pil 'beside' (cf. pil 'hip') and put-pun 'above' suggests it may have originally contained a meaning to do with proximity (or perhaps protrusion, as something beside or above an object must necessarily extend out from that object).

\subsection{Configurational parts, growths, excreta and traces}

Only two real configurational body part terms have been elicited to date: $k u l$ 'lap' and yuur-wang 'fist' (lit. 'hand-white') (owing to the pale knuckles of a tightly clenched hand). ${ }^{28}$ Nominals referring to a configuration of the body as a whole include pungk-nganp 'cross-legged' (lit. 'knee-NGANP') (cf. man-nganp 'shadow', lit. 'throat-NGANP'), manwal-rumparr 'head bowed forwards' (lit. 'throat-temple-break') and pungk-kul 'curled up' (lit. 'knee-lap'). A number of terms for bodily products are presented in Table 4, many of which were discussed in Section 2. As noted in Section 3, while lexemes like man-nganp 'shadow' and thamr-rathr 'footfall' may not appear good candidates for parts of the body, they pattern with other (more conventional) body parts on all relevant syntactic and semantic tests. Like excreta and other bodily products, these 'traces' are issued from the body and in many respects stand for the whole person (e.g. a person's identity or whereabouts may be discerned from their voice, footprints or shadow). This collection of miscellaneous body parts in Table 4 completes the inventory of body part terms compiled to date.

\section{Parts of animals}

For the most part, body part terms may be used equally to describe the parts of humans and parts of animals. At this stage of investigation, it is unclear whether terms such as yangkar 'calf of human'/'leg of dog'/'tail of fish'/etc. and thaaw 'mouth of human'/'mouth of $\mathrm{dog}^{\prime} /$ 'beak of bird'/etc. are semantically general ${ }^{29}$ or polysemous, and if the latter, whether or not reference to the human body part is primary. As noted above, in the case of internal organ terminology in particular, we might expect originally animal-part terms to extend to humans rather than the reverse.

While the similarities between the mouths of humans and of dogs (and other mammals) may point towards the vagueness of terms like thaaw 'mouth', the correspondence between some other human and animal parts described by the same term is less exact. Exemplifying

\footnotetext{
28 Many other bodily configurations (such as 'smile', 'frown', etc.) are expressed by verbs in Kuuk Thaayorre.

29 If semantically general, these terms could be functionally defined as (roughly) 'the body part primarily involved in propulsion' and 'the body part used in consumption' respectively.
} 
Table 4

Configurational parts, growths, excreta and traces

\begin{tabular}{|c|c|c|}
\hline Thaayorre term & Translation & Gloss \\
\hline \multicolumn{3}{|l|}{ Simplex } \\
\hline kam & 'blood' & 'blood' \\
\hline kul & 'lap' & 'lap' \\
\hline kun & 'faeces' & 'faeces' \\
\hline kuuk & 'voice' & 'word, language' \\
\hline mayil & 'pimple' & 'pimple' \\
\hline nhumurr & 'sweat' & 'sweat' \\
\hline pirp & 'semen' & 'semen' \\
\hline puungk & 'bruise, swelling' (Foote and Hall, 1992, p. 121) & 'bruise' \\
\hline rerp & 'scar' & 'scar' \\
\hline thangk & 'pus' & 'pus' \\
\hline thethor & 'pimple' (Foote and Hall, 1992, p. 158) & 'pimple' \\
\hline thiiy & 'urine' & 'urine' \\
\hline \multicolumn{3}{|l|}{ Complex } \\
\hline koo-nhij & 'snot' & 'nose-NHIJ' \\
\hline man-nganp & 'shadow' & 'throat-NGANP' \\
\hline man-nhunk & 'phlegm, cough' & 'throat-phlegm, cough' \\
\hline man-paat & 'burp' & 'throat-uteral.fluid' \\
\hline man-pitl & 'hiccup' & 'throat-PITL' \\
\hline man-wal-rumparr & 'head bowed forwards' & 'throat-temple-break' \\
\hline meer-mak-key & ‘scab' (Foote and Hall, 1992, p. 59) & 'eye-MAK-KEY' \\
\hline meer-ngok & 'tear' & 'eye-water' \\
\hline (ngeengk-)nherp & 'soul, spirit' & '(belly-)spirit' \\
\hline (ngok-)paat & 'uteral fluid' (Foote and Hall, 1992, p. 97) & ‘(water-)uteral.fluid’ \\
\hline pungk-kul & 'curled up' & 'knee-lap' \\
\hline pungk-nganp & 'cross-legged' & 'knee-NGANP' \\
\hline punth-nherp & 'heartbeat' & ‘arm-spirit' \\
\hline thamr-kamp & 'footprint' & 'foot-blood:EMPH' \\
\hline thamr-rathr & 'footfall' & 'foot-RATHR' \\
\hline yin-kam & 'menstrual blood' & 'female.sex.organ-blood' \\
\hline yuur-wang & 'fist' & 'hand-white' \\
\hline
\end{tabular}

this are meer-mak-key '(human) scab' or '(fish) scale' (Foote and Hall, 1992, p. 59) and kap 'area under (human) arm' or '(fish) fin'. ${ }^{30}$ Other animal parts, lacking obvious analogues in the human body, are referred to using terms reserved exclusively for those animals, such as maarr 'feather'; purranth 'large feather, plume' (Foote and Hall, 1992, p. 119); and poopun 'fur'. In some cases, complex animal part terms are formed (at least in part) from terms for human body parts: kirk-koow 'stingray barb' (lit. 'spear-nose'); kaal-kay 'horn' (lit. 'ear-metal'); yin-poor 'pouch' (lit. 'vagina-POOR'); paant-thaaw '(whale) blowhole' (lit. 'head-mouth'). Fish tails may be referred to either as yangkar 'calf' or kun-pothun 'tail' (lit. 'bum-POTHUN'). Kun-pothun may also describe the tails of birds, while the tails of dogs, marsupials and most other animals must be referred to as kun-mul (lit. 'bumMUL'). Gaby (2004a) describes the reanalysis of some of these animal part terms in the speech of Thaayorre children.

\footnotetext{
${ }^{30}$ Note, however, that Foote and Hall (1992, p. 34) differentiate kap 'armpit' from kaap 'fin'.
} 


\section{Other uses of body part terms}

The majority of lexemes listed in Section 4 tables are (highly) polysemous. Where comparative data are available, the body part sense is most commonly historically prior. Synchronically, too, the body part sense appears to remain the core meaning-the one speakers will most readily proffer in defining or explaining the term. The extended meanings they come to encode, however, vary enormously.

To begin with, body part terms may be used in reference to whole non-human entities, such as minh kaal 'rat' (lit. 'animal ear') or may pukal 'waterlily' (lit. 'vegetable.food umbilical.cord'). The segmentation of the body is also regularly mapped onto the landscape. Hills and sand ridges can be described as raak muth 'neck place', while the ocean has ngok pungk 'waves' (lit. 'water knee'). The surface of the ground can be described as raak koomiing (lit. 'place face'). Objects such as trees are described as having punth 'branches' (lit. 'arms') and wuurr 'twigs' (lit. 'digits'). Most objects (e.g. houses, computers, bags) can be described with respect to their paant 'top' (lit. 'head') and kun 'bottom' or 'end' (lit. 'bum'), and where there is a salient opening or hole (as with a bag or a bottle) this may be referred to as thaaw 'mouth'. Body part terms are also further extended to describe spatial relationships (e.g. kun-koorre 'backwards' (lit. 'bottom-behind') and punth thak 'left (hand) side' (lit. 'arm left')). Further grammaticalised functions of body part terms (e.g. in the description of kinship relations, activities, emotions and traits) are discussed in Gaby (2004a,b).

\section{Conclusions}

This paper is the first systematic study of body part terminology in Kuuk Thaayorre, listing over 150 body part lexemes in the tables of Section 4. Beyond listing the terms themselves, the previous sections have analysed the morphological form and semantic composition of analysable terms; considered possible motivations for creating new body part terms, both in the prehistory of the language and in continuing developments; and (perhaps most importantly) questioned the relationship that holds between parts of the body, as well as the concept of 'body' itself. This paper has placed Kuuk Thaayorre amongst the growing number of languages shown to adhere to neither a taxonomic nor partonomic model in their subdivision of the human form.

The extension of Thaayorre body part terms to categorise and describe non-human entities and events reveals the numerous ways in which the segmentation of the body is mapped onto the outside world. The prevalence of these (often grammaticalised) body part terms throughout Thaayorre discourse makes an understanding of body part terminology prerequisite to understanding both the grammatical system as a whole, and the ways in which Thaayorre speakers view themselves and the world in which they live.

\section{Acknowledgements}

The research reported in this paper was supported by the Max Planck Society and the University of Melbourne. Miriam van Staden, Niclas Burenhult, Asifa Majid, Nick Enfield, Stephen Levinson and Angela Terrill inspired my interest in body part terminology as a domain of research and provided me with excellent models of elicitation and analysis. 
The comments of three anonymous reviewers, along with the editors, Niclas Burenhult and Erich Round, were particularly useful in refining my analysis. Any remaining errors are of course my own. Above all, I thank my Thaayorre language teachers and consultants for their insights, patience and good humour. My research would not have been possible without the generosity of the Thaayorre community and the support of the Pormpuraaw Aboriginal Council.

\section{Appendix}

\section{Glossary of terms}

$\begin{array}{ll}1 & \text { first person } \\ 2 & \text { second person } \\ 3 & \text { third person } \\ \text { ACC } & \text { accusative case } \\ \text { AddrFam } & \text { familiar to addressee } \\ \text { CNTR } & \text { contrastive particle } \\ \text { DESID } & \text { desiderative } \\ \text { ERG } & \text { ergative case } \\ \text { GEN } & \text { genitive case } \\ \text { IMPER } & \text { imperative mood } \\ \text { IPF } & \text { imperfect tense } \\ \text { LOC } & \text { locative case } \\ \text { NOM } & \text { nominative case } \\ \text { PERF } & \text { perfective } \\ \text { PROHIB } & \text { prohibitive particle } \\ \text { PROP } & \text { proprietive } \\ \text { RDP } & \text { reduplication } \\ \text { REFL } & \text { reflexive } \\ \text { Sg } & \text { singular number }\end{array}$

\section{References}

Alpher, B., 1992. Yir-Yoront Lexicon: Sketch and Dictionary of an Australian Language. Mouton de Gruyter, Berlin.

Anderson, E.S., 1978. Lexical universals of body-part terminology. In: Greenberg, J.H. (Ed.), Universals of Human Language, Word Structure, vol. 3. Stanford University Press, Stanford, pp. 335-368.

Berlin, B., Breedlove, D.E., Raven, P.H., 1966. Folk taxonomies and biological classification. Science 154, $273-$ 275.

Blake, B., 1990. Problems of possessor ascension: some Australian examples. Linguistics 22, 437-453.

Brown, C.H., 1976. General principles of human anatomical partonomy and speculations on the growth of partonomic nomenclature. American Ethnologist 3, 400-424.

Brown, C., Witkowksi, S., 1981. Figurative language in a universalist perspective. American Ethnologist 8, 596615.

Burenhult, N., this volume. Body part terms in Jahai. In: Majid, A., Enfield, N.J., van Staden, M. (Eds.), Parts of the Body: Cross-Linguistic Categorisation. Special Issue of Language Sciences.

Chappell, H., McGregor, W., 1996. The Grammar of Inalienability: A Typological Perspective on the PartWhole Relation. Mouton de Gruyter, Berlin. 
Dixon, R.M.W., 1980. The Languages of Australia. Cambridge University Press, Cambridge.

Enfield, N.J., this volume-a. Elicitation guide on parts of the body. In: Majid, A., Enfield, N.J., van Staden, M. (Eds.), Parts of the Body: Cross-Linguistic Categorisation. Special Issue of Language Sciences.

Enfield, N.J., this volume-b. Lao body part terms. In: Majid, A., Enfield, N.J., van Staden, M. (Eds.), Parts of the Body: Cross-Linguistic Categorisation. Special Issue of Language Sciences.

Enfield, N.J., Majid, A., van Staden, M., this volume. Cross-linguistic categorisation of the body: introduction. In: Majid, A., Enfield, N.J., van Staden, M. (Eds.), Parts of the Body: Cross-Linguistic Categorisation. Special Issue of Language Sciences.

Evans, N., 1992. Multiple semiotic systems, hyperpolysemy, and the reconstruction of semantic change in Australian languages. In: Kellerman, G., Morrissey, M. (Eds.), Diachrony Within Synchrony. Peter Lang Verlag, Bern, pp. 475-508.

Evans, N., 1997. Sign metonymies and the problem of Flora-fauna polysemy in Australian linguistics. In: Tryon, M., Walsh, M. (Eds.), Boundary Rider. Essays in Honour of Geoffrey O’Grady. Pacific Linguistics, Canberra, p. C-136.

Evans, N., Wilkins, D., 2001. The complete person: networking the physical and the social. In: Simpson, J., Nash, M., Laughren, M., Austin, P., Alpher, B. (Eds.), Forty Years On: Ken Hale and Australian Languages. Pacific Linguistics, Canberra, pp. 493-521.

Foote, T., Hall, A.H., 1992. Kuuk Thaayorre Dictionary: Thaayorre/English. Jolen Press, Toowoomba.

Gaby, A., 2004a. Extended Uses of Thaayorre Body Part Terminology. Melbourne Papers in Linguistics and Applied Linguistics. University of Melbourne, Melbourne, pp. 21-32.

Gaby, A., 2004b. The body familiar: categorising kin relations in Thaayorre oral and manual registers. Paper presented at International Language and Cognition Conference, 10th September. University of New England, Coffs Harbour.

Hale, K., 1981. Preliminary remarks on the grammar of part-whole relations in Warlpiri. In: Hollyman, J., Pawley, A. (Eds.), Studies in Pacific Linguistics in Honor of Bruce Biggs. Linguistic Society of New Zealand, Auckland, pp. 333-344.

Heine, B., 1997. Cognitive Foundations of Grammar. Oxford University Press, Oxford.

Levinson, S.C., 2000. Presumptive Meanings: The Theory of Generalised Conversational Implicature. MIT Press, Cambridge.

Majid, A., this volume. Body part categorisation in Punjabi. In: Majid, A., Enfield, N.J., van Staden, M. (Eds.), Parts of the Body: Cross-Linguistic Categorisation. Special Issue of Language Sciences.

McClure, E., 1975. Ethno-anatomy: the structure of the domain. Anthropological Linguistics 17, 78-88.

McGregor, W., 1985. Body parts in Kuniyanti clause grammar. Australian Journal of Linguistics 5, 209-232.

McGregor, W., 1999. External possession constructions in Nyulnyulan languages. In: Payne, D., Barshi, I. (Eds.), External Possession. John Benjamins, Amsterdam.

Meira, S., this volume. Tiriyó body part terms. In: Majid, A., Enfield, N.J., van Staden, M. (Eds.), Parts of the Body: Cross-Linguistic Categorisation. Special Issue of Language Sciences.

Nichols, J., 1988. On alienable and inalienable possession. In: Shipley, W. (Ed.), In Honour of Mary Haas: From the Haas Festival Conference on Native American Linguistics. Mouton de Gruyter, Berlin.

Palmer, G., Nicodemus, L., 1985. Coeur d'Alene exceptions to proposed universals of anatomical nomenclature. American Ethnologist 12, 341-359.

Payne, D., Barshi, I. (Eds.), 1999. External Possession. John Benjamins, Amsterdam.

Smith, I., Johnson, S., 2000. Kugu Nganhcara. In: Dixon, R.M.W., Blake, B.J. (Eds.), The Handbook of Australian Languages, vol. 5. Oxford University Press, Melbourne, pp. 357-489.

Wierzbicka, A., 1994. Semantic primitives across languages: a critical review. In: Goddard, C., Wierzbicka, A. (Eds.), Semantic and Lexical Universals. John Benjamins, Amsterdam, pp. 445-500.

Wilkins, D., 1996. Natural tendencies of semantic change and the search for cognates. In: Durie, M., Ross, M. (Eds.), The Comparative Method Reviewed: Regularity and Irregularity in Language Change. Oxford University Press, Oxford.

Winston, M., Chaffin, R., Herrmann, D., 1987. A taxonomy of part-whole relations. Cognitive Science 11, 417444. 